\title{
KONSTRUKSI MODEL PEMBELAJARAN BERBASIS KECERDASAN SPIRITUAL UNTUK PERBAIKAN KARAKTER
}

\section{Construction of Spiritual Intelligence-Based Learning for Character Buildings}

\author{
Muhammad Yaumi \\ Universitas Islam Negeri Alauddin Makassar \\ J1. Sultan Alauddin No.36 Samata-Gowa \\ Email: muhammadyaumi@yahoo.com \\ Sitti Fatimah S.Sirate \\ Sekolah Tinggi Keguruan dan Ilmu Pendidikan \\ Yayasan Pendidikan Ujung Pandang \\ J1. Andi Tonro Makassar \\ Email: fatimahsirate@yahoo.com
}

\begin{abstract}
Abstrak
Tujuan penelitian ini adalah untuk menganalisis kondisi objektif pelaksanaan pembelajaran yang mengintegrasikan nilai-nilai karakter, mengungkap konstruksi model pembelajaran berbasis kecerdasan spiritual untuk perbaikan karakter, dan mendeskripsi model perbaikan karakter melalui program pembelajaran berbasis kecerdasan spiritual. Penelitian ini menggunakan metode penelitian kualitatif. Metode pengumpulan data menggunakan lembar observasi partisipan dalam bentuk partisipasi moderat, pedoman wawancara kelompok fokus dan lembar 'checklist' dokumen. Analisis data dalam penelitian ini menggunakan analisis data kualitatif dengan merujuk pada tiga tahap analisis, seperti reduksi data, sajian data, dan penarikan kesimpulan/verifikasi. Hasil penelitian menunjukkan bahwa model integrasi nilai-nilai karakter dalam pembelajaran dapat dilakukan melalui integrasi pengetahuan konten, proses pembelajaran, lingkungan belajar, kegiatan ekstrakurikuler, dan pemberdayaan budaya dan stuktur sosial dalam lingkungan sekolah. Model pembelajaran berbasis kecerdasan spiritual mencakup penentuan strategi implementasi, prosedur penerapan, integrasi tugas, pengawasan pelaksanaan, dan evaluasi proses dan hasil. Perbaikan karakter dilakukan melalui Baca Tulis Alquran, Taman Baca Sekolah, dan Kantin Kejujuran.
\end{abstract}

Kata kunci: desain pembelajaran, pendidikan karakter, kecerdasan spiritual

Abstract

The purpose of this study was to analyze the objective condition of instructional implementation that integrates values character, reveals the construction of spiritual intelligence-based learning model for the character improvement, and describes the character improvement model through spiritual intelligencebased learning programs. This study used a qualitative research method. Methods of data collection was participant observation sheet in the form of a moderate participation, focus group interview guide and the document checklist. The method of data analysis used in this study were data reduction, data displays, and conclusion and verification. The results showed that the integration model of character values in instruction were done through content knowledge integration, instructional process, learning environment, extracurricular activities, and cultural empowerment and social structures within the school environment. Spiritual intelligence-based learning model includes determining the implementation strategy, application procedures, integration tasks, execution, and evaluation of instructional process and result. Character improvement was done through Quranic literacy, reading park, and honesty cave programs.

Keywords: learning design,character building, spiritual question 


\section{PENDAHULUAN}

$\mathrm{P}$ embangunan karakter dan budaya adalah upaya kolektif bangsa dalam rangka mengangkat harkat dan martabat bangsa, serta manusia Indonesia seutuhnya. Fenomena kemerosotan moral dan degradasi akhlak yang mengemuka belakangan ini telah mengancam sendi-sendi keteladanan sikap dan perilaku sebagian komunitas anak bangsa. Penyimpangan perilaku seperti praktik korupsi, konsumsi narkoba, tawuran massal, demonstrasi anarkis, dan berbagai bentuk tindakan melawan hukum lainnya adalah dampak dari kemerosotan moral. Hal ini telah menginspirasi para ilmuwan dan praktisi pendidikan untuk mengambil langkah antisipatif dengan mengintegrasikan nilai-nilai karakter dalam pembelajaran (Yaumi, 2014). Langkah tersebut dipandang sangat efektif untuk mengonstruksi dan merekat bangunan akhlak dan budi pekerti yang luhur sebagai landasan terbangunnya Indonesia emas yang lebih berperadaban dan berperikemanusiaan (Dewantara, 1977).

Keadaban bangsa Indonesia telah lama menjadi cita-cita bersama dan selalu menjadi inti tujuan pendidikan nasional. Undang-undang No. 2/1989, pasal 4 mencantumkan bahwa "Pendidikan nasional bertujuan mencerdaskan kehidupan bangsa dan mengembangkan manusia Indonesia seutuhnya, yaitu manusia yang beriman dan bertakwa terhadap Tuhan Yang Maha Esa dan berbudi-pekerti luhur, memiliki pengetahuan dan keterampilan, kesehatan jasmani dan rohani, kepribadian yang mantap dan mandiri serta rasa tanggung-jawab kemasyarakatan dan kebangsaan." Begitu pula tujuan pendidikan nasional sebagaimana tercantum dalam UndangUndang No. 20, Tahun 2003, Pasal 3 menyebutkan bahwa "Pendidikan nasional berfungsi mengembangkan kemampuan dan membentuk watak serta peradaban bangsa yang bermartabat dalam rangka mencerdaskan kehidupan bangsa, bertujuan untuk berkembangnya potensi peserta didik agar menjadi manusia yang beriman dan bertakwa kepada Tuhan Yang Maha Esa, berakhlak mulia, sehat, berilmu, cakap, kreatif, mandiri, dan menjadi warga negara yang demokratis serta bertanggung jawab."

Beriman, bertakwa, berbudi pekerti luhur, berpengetahuan berketerampilan, memiliki kesehatan jasmani dan rohani, berkepribadian mantap, mandiri, dan tanggung jawab, sebagaimana tercantum dalam undang-undang tersebut dipandang sebagai nilai-nilai spiritual yang digali dan dikembangkan dari budaya, tradisi, dan agama yang dianut oleh mayoritas manusia Indonesia. Nilai-nilai spiritual ini berkorelasi langsung dengan kehidupan keagamaan, kebahagiaan, kesadaran paling dalam, motivasi, kepuasan kerja, dan strategi pembelajaran. Temuan yang ditunjukkan oleh Baharuddin dan Ismail (2013) menunjukkan bukti bahwa kecerdasan rohaniah warga tua dengan amalan agama di Rumah Kebajikan mempunyai hubungan positif yang signifikan. Warga tua yang mempunyai domain spiritual yang tinggi menyebabkan mereka senang untuk melaksanakan amal ibadah dalam kehidupan keseharian mereka. Begitu pula studi yang dilakukan oleh Isfahani dan Nobakht (2013) yang menemukan bahwa terdapat hubungan signifikan antara kecerdasan spiritual dengan kebahagian. Kecerdasan spiritual memicu terbentuknya kemampuan dan keterampilan yang menyebabkan mereka cenderung sangat aktif dan memengaruhi konteks sosial dan sejarah yang berbeda dengan orang lain umumnya dan oleh karena itu mereka tidak pernah takut menghadapi kehidupan yang menyebabkan mereka mampu mengatasi berbagai permasalahan yang dihadapi untuk mengantarkan pada kepuasan batin, kebahagiaan hidup, dan kesadaran yang mendalam.

Dalam dunia kerja, kecerdasan spiritual memberi dampak positif pada pemberdayaan staf dan kepuasan kerja. Studi yang dilakukan oleh Mosaybian dan Araghizade (2014) tentang pengaruh kecerdasan spiritual terhadap pemberdayaan pegawai menunjukkan bahwa kecerdasan spiritual berdampakpositifpadapemahamanpegawai tentang kompetensi, efektivitas kerja, dan kebermaknaan suatu pekerjaan. Begitu pula temuan Jeloudar dan Goodarzi (2012) yang mengaji hubungan antara kecerdasan spiritual dengan kepuasan kerja. Mereka menemukan bahwa terdapat hubungan signifikan antara guru yang memiliki kecerdasan spiritual yang tinggi dengan dengan lima factor kepuasan kerja termasuk hakikat kerja, sikap terhadap pengawas, hubungan dengan teman kerja, kesempatan untuk promosi jabatan, dan kondisi kerja dalam lingkungan lembaga pendidikan mereka.

Kajian lain yang lebih khusus dengan kecerdasan spiritual dan pembelajaran dilakukan oleh Azizi dan Zamaniyan (2013) yang menelaah hubungan antara kecerdasan spiritual dengan strategi belajar kosakata (vocabulary) bagi peserta didik yang bahasa Inggris sebagai bahasa asing (English as a Foreign Language). Hasil temuan menunjukkan peserta didik laki-laki yang memiliki skor yang lebih tinggi daripada peserta didik wanita dalam penggunaan strategi belajar kosakata bahasa Inggris dan peserta didik wanita yang memiliki skor yang lebih tinggi dari pada peserta didik lakilaki ditemukan memiliki skor kecerdasan spiritual yang lebih tinggi.

Semuahasilstudiyangdilakukanmenunjukkan 
bahwa kecerdasan spiritual member! kontribusi yang sangat besar dalam pembangunan karakter peserta didik. Sekalipun demikian, kajian yang langsung diarahkan pada konstruksi model untuk menjadi pijakan dasar dalam mengimplementasi dan mengintegrasikan nilai-nilai spiritual ke dalam pembelajaran belum banyak menarik perhatian para ilmuwan. Oleh karena itu, Maimun (2008) memberi rekomendasi untuk mengembangkan dan mengonstruksi model pembelajaran berbasis nilai termasuk nilai-nilai spiritual dan karakter bangsa.

\section{Tinjauan Pustaka}

Konstruksi berasal dari kata konstruk yang keberadaan dan sifatnya tidak dapat secara langsung atau otomatis disimpulkan dalam bentuk empiris dan oleh karena itu, hanya dapat dijelaskan atas dasar jaringan operasi konvergen (Snelbecker, 1974). Konstruksi (construction) dalam hubungannya dengan pembelajaran (instruction) berkenaan dengan dengan peran peserta didik dalam membangun ilmu pengetahuan setelah berhasil memadukan antara pengalaman di masa lalu dengan apa yang sedang dipelajari untuk mengonstruksi pengetahuan baru (Reigeluth, 2009). Dalam Online Business Dictionary dijelaskan bahwa yang dimaksud dengan model adalah representasi gratis, matematika (simbolik), fisik, maupun lisan atau versi sederhana dari suatu konsep, fenomena, hubungan, struktur, sistem, atau aspek dari dunia nyata. Definisi ini mencakup seluruh jenis model mulai dari yang sederhana sampai model teknologi canggih, mulai dari model yang sedikit abstrak sampai model dalam bentuk fisik.

Definisi lain diberikan oleh Snelbecker (1974: 32) yang mengatakan bahwa "model is a concretization of a theory which is meant to be analogous to or representative of the process and variables involved in the theory. (Model adalah konkretisasi/ perwujudan teori yang dimaksudkan untuk menjadi analog atau wakil dari proses dan variabel yang terlibat dalam teori)". Definisi ini menekankan bahwa model adalah sesuatu yang berwujud dalam bentuk fisik atau dapat dikatakan merupakan penjabaran teori untuk dijadikan acuan dalam menjalankan sesuatu. Model yang dikemukakan di sini lebih khusus pada representasi analogi dari suatu konsep dan teori. Definisi yang lebih spesifik yang berkenaan dengan bidang pendidikan adalah definisi yang diberikan oleh Prawiradilaga (2007: 33) yang mengartikan model sebagai tampilan grafts, prosedur kerja yang teratur dan sistematis, serta mengandung pemikiran bersifat uraian atau penjelasan berikut saran. Terdapat tiga komponen yang menjadi penekanan dalam definisi ini, yakni (1) tampilan grafts; bagan, skema, peta, dan diagram jaringan, (2) prosedur kerja yang teratur dan sistematis; LKS/LKM, modul, buku ajar, buku petunjuk belajar, metode, strategi, media, dan sebagainya, serta (3) pemikiran bersifat uraian atau penjelasan; model yang merepresentasikan teori dan konsep seperti teori belajar dan pembelajaran, psikologi, komunikasi, bisnis, perdagangan, dan sebagainya. Dengan demikian, rekonstruksi model dalam penelitian ini merupakan konkretisasi proses pebelajaran yang menggunakan pendekatan pembelajaran berbasis kecerdasan spiritual.

Kecerdasan spiritual disebut pula kecerdasan eksistensial adalah kemampuan untuk mengajukan pertanyaan-pertanyaan fundamental tentang eksistensi (keberadaan) atau pertanyaan tentang kerumitan suatu eksistensi (Wilson dalam Yaumi, 2013). Gardner (1999: 60) mengusulkan definisi kecerdasan spiritual sebagai kecerdasan eksistensial yang mampu menempatkan diri dalam hubungannya dengan suatu kosmos yang tak terbatas dan sangat kecil serta kapasitas untuk menempatkan diri dalam hubungannya dengan fitur-fitur eksistensial dari suatu kondisi manusia seperti makna kehidupan, arti kematian, perjalanan akhir dari dunia fisik dan psikologis, dan pengalaman mendalam tentang cinta kepada orang lain atau perendaman diri secara total dalam suatu karya seni. Secara khusus, Gardner tidak mengusulkan bahwa terdapat kecerdasan spiritual, religius, atau moral berdasarkan kebenaran dari suatu keyakinan individu, golongan, kelompok, atau institusi tertentu.

Meskipun demikian, kecerdasan spiritual belum sesuai dengan kriteria yang dikembangkan oleh Gardner sehingga kecerdasan ini dipandang belum sepenuhnya memenuhi syarat untuk masuk ke dalam teori kecerdasan jamak. Namun, terdapat alasan yang menjamin kecerdasan ini dimasukkan sebagai kecerdasan yang kesembilan dalam studi kecerdasan jamak. Amstrong (2009: 184185) memberikan petunjuk awal jika kecerdasan spitritual diterapkan dalam pembelajaran. Pertama, perlu ditekankan bahwa kecerdasan spiritual bukanlah untuk mempromosikan persoalan agama, spiritualitas, atau sistem kepercayaan tertentu, tetapi didedikasikan untuk mengkaji berbagai cara bagaimana manusia menjawab kekhawatiran eksistensial (baik menyangkut persoalan agama maupun yang bukan agama) termasuk keragaman cara yang dilakukan oleh berbagai pihak. Ada perlindungan konstitusional yang jelas untuk mengajar agama pada sekolah-sekolah umum secara objektif dan netral dan alasan pedagogis untuk menerapkan hal "ini secara teratur melalui kurikulum.

Kedua, penerapan kecerdasan eksistensial masih memerlukan pertimbangan mendalam dan 
hati-hati dibandingkan delapan jenis kecerdasan lainnya. Menurut Amstrong hampir tidak terlihat keuntungan khusus dalam menerapkan kecerdasan eksistensial untuk setiap tujuan pendidikan walaupun kecerdasan ini sepenuhnya didukung oleh Howard Gardner sebagai kecerdasan resmi pada suatu hari nanti, tetap menjadi bagian yang berbeda dengan jenis kecerdasan lain. Ketiga, untuk menilai kecerdasan eksistensial pada peserta didik, atau untuk mengembangkan metode eksistensial dalam menilai topik-topik tertentu yang dikaji, sama sekali tidak produktif atau berguna dalam konteks pendidikan karena mereka cenderung untuk memaksa pendidik menciptakan kriteria yang terlalu membatasi nilai pedagogis sehingga mungkin hanya untuk mendorong munculnya kontroversi dan kebingungan baru.

Kekhawatiran Amstrong tersebut sebenarnya wajar-wajar saja dalam suatu masyarakat yang memisahkan agama dengan Negara bahkan dalam konteks kehidupan sehari-hari. Dalam suatu falsafah Negara Pancasila seperti halnya Indonesia, di mana sila pertamanya menyangkut "Ketuhanan Yang Maha Esa" penerapan kecerdasan eksistensial atau spiritual menjadi sangat penting artinya. Selain itu, paham kesatuan dalam keberagaman (unity in diversity) yang dianut bangsa Indonesia, menjadi petunjuk yang kuat untuk mengalamatkan kecerdasan eksistensial dalam pembelajaran. Oleh karena itu, penulis bisa memahami kehati-hatian Gardner dan Amstrong dalam memasukkan kecerdasan eksistensial sebagai kecerdasan yang kesembilan. Namun, tidak sedikit juga para pendidik telah menggolongkan kecerdasan ini ke dalam bahagian yang tak terpisahkan dengan kecerdasan jamak.

Connell (2005: 60) berbicara tentang kecerdasan spiritual dan mengatakan "Existential intelligence is the intelligence that Gardner refers to as half intelligence because he could not find a physiological location for it in the brain. I also call this a spiritual intelligence, as those who score high in this intelligence are concerned with life's big questions." Pernyataan ini paling tidak memberi isyarat yang jelas pada duahal utama. Pertama, bahwa Howard Gardner sendiri masih mendudukkan kecerdasan spiritual sebagai kecerdasan setengah atau belum sempurna menjadi suatu kecerdasan hanya dengan alasan karena belum ditemukan lokasi fisiologisnya dalam otak manusia. Jika pernyataan ini benar, berarti kalau ditemukan tempatnya yang jelas dalam bagian otak manusia, maka Gardner dapat menerimanya sebagai kecerdasan yang sempurna. Kedua, kecerdasan eksistensial disebut juga kecerdasan spiritual karena fokus kajiannya menyangkut pertanyaan-pertanyaan besar dalam kehidupan manusia.

Gardner (1999: 54-60) ketika menjelaskan tentang kemungkinan adanya kecerdasan spiritual, dia membaginya dalam tiga komponen, yaitu (1) spiritual as concern with cosmic or existential issues; (2) spiritual as achievement of a state of being; dan (3) spiritual as effect on others. Maksudnya spiritual dalam hubungannya dengan kosmik atau isu-isu eksistensial, spiritual sebagai pencapaian keberadaan manusia, dan spiritual yang menimbulkan pengaruh bagi orang lain. Dengan demikian, sebenarnya Gardner sendiri telah memberi isyarat bahwa antara kecerdasan spiritual dan eksistensial memiliki bidang kajian yang sama untuk dilihat dan dikaji lebih dalam guna mengungkap bukti-bukti autentik yang dapat mengantarkan kepada kesimpulan untuk memasukkan secara resmi kecerdasan spiritual atau eksistensial ke dalam kajian kecerdasan jamak.

Kata spiritual memiliki akar kata spirit yang berarti roh. Kata ini berasal dari bahasa Latin, spiritus, yang berarti napas (Mitrafam, 2011). Roh bisa diartikan sebagai tenaga yang menjadi energi kehidupan, yang membuat manusia dapat hidup, bernapas dan bergerak. Dalam ajaran agama Kristen dijelaskan bahwa Roh Kudus adalah Allah, Roh Kudus adalah sebuah Pribadi yang memiliki akal budi, perasaan dan kehendak (Kisah Rasul 5:34 dan Yohanes 14:16, 26; 15:26). Begitu pula dalam Alquran dijelaskan bahwa:

\footnotetext{
"Katakanlah: Roh Kudus (Jibril) menurunkan Alquran itu dari Tuhanmu dengan benar, untuk meneguhkan (hati) orang-orang yang telah beriman, dan menjadi petunjuk serta kabar gembira bagi orang-orang yang berserah diri (kepada Allah)". (QS. 16:102).
}

Frase ruhu-alkudus, dalam ayat tersebut merujuk pada Malaikat Jibril yang diberi tugas mulia oleh Allah untuk membawa Alquran sebagai pedoman hidup manusia. Sedangkan, dalam kedua ayat berikut ini, ruh berdiri sendiri, tetapi didahului oleh haruf min yang diartikan roh ciptaanNya.

"Kemudian Dia menyempurnakan dan meniupkan ke dalam (tubuh)nya roh (ciptaan) Nya dan Dia menjadikan bagi kamu pendengaran, penglihatan dan hati; (tetapi) kamu sedikit sekali bersyukur (QS. 32:09)."

"Maka apabila Aku telah menyempurnakan kejadiannya dan - telah meniupkan ke dalamnya roh (ciptaan)-Ku, maka tunduklah kamu kepadanya dengan bersujud (QS, 15: 29)."

Menurut Nasri (2011) terdapat poin penting 
bahwa kecerdasan spiritual memberi kontribusi yang sangat besar dalam pembangunan karakter peserta didik. Sekalipun demikian, kajian yang langsung diarahkan pada konstruksi model untuk menjadi pijakan dasar dalam mengimplementasi dan mengintegrasikan nilai-nilai spiritual ke dalam pembelajaran belum banyak menarik perhatian para ilmuwan. Oleh karena itu, Maimun (2008) memberi rekomendasi untuk mengembangkan dan mengonstruksi model pembelajaran berbasis nilai termasuk nilai-nilai spiritual dan karakter bangsa.

\section{Tinjauan Pustaka}

Konstruksi berasal dari kata konstruk yang keberadaan dan sifatnya tidak dapat secara langsung atau otomatis disimpulkan dalam bentuk empiris dan oleh karena itu, hanya dapat dijelaskan atas dasar jaringan operasi konvergen (Snelbecker, 1974). Konstruksi (construction) dalam hubungannya dengan pembelajaran (instruction) berkenaan dengan dengan peran peserta didik dalam membangun ilmu pengetahuan setelah berhasil memadukan antara pengalaman di masa lalu dengan apa yang sedang dipelajari untuk mengonstruksi pengetahuan baru (Reigeluth, 2009). Dalam Online Business Dictionary dijelaskan bahwa yang dimaksud dengan model adalah representasi grafis, matematika (simbolik), fisik, maupun lisan atau versi sederhana dari suatu konsep, fenomena, hubungan, struktur, sistem, atau aspek dari dunia nyata. Definisi ini mencakup seluruh jenis model mulai dari yang sederhana sampai model teknologi canggih, mulai dari model yang sedikit abstrak sampai model dalam bentuk fisik.

Definisi lain diberikan oleh Snelbecker (1974: 32) yang mengatakan bahwa "model is a concretization of a theory which is meant to be analogous to or representative of the process and variables involved in the theory. (Model adalah konkretisasi/ perwujudan teori yang dimaksudkan untuk menjadi analog atau wakil dari proses dan variabel yang terlibat dalam teori)". Definisi ini menekankan bahwa model adalah sesuatu yang berwujud dalam bentuk fisik atau dapat dikatakan merupakan penjabaran teori untuk dijadikan acuan dalam menjalankan sesuatu. Model yang dikemukakan di sini lebih khusus pada representasi analogi dari suatu konsep dan teori. Definisi yang lebih spesifik yang berkenaan dengan bidang pendidikan adalah definisi yang diberikan oleh Prawiradilaga (2007: 33) yang mengartikan model sebagai tampilan grafis, prosedur kerja yang teratur dan sistematis, serta mengandung pemikiran bersifat uraian atau penjelasan berikut saran. Terdapat tiga komponen yang menjadi penekanan dalam definisi ini, yakni (1) tampilan grafis; bagan, skema, peta, dan diagram jaringan, (2) prosedur kerja yang teratur dan sistematis; LKS/LKM, modul, buku ajar, buku petunjuk belajar, metode, strategi, media, dan sebagainya, serta (3) pemikiran bersifat uraian atau penjelasan; model yang merepresentasikan teori dan konsep seperti teori belajar dan pembelajaran, psikologi, komunikasi, bisnis, perdagangan, dan sebagainya. Dengan demikian, rekonstruksi model dalam penelitian ini merupakan konkretisasi proses pebelajaran yang menggunakan pendekatan pembelajaran berbasis kecerdasan spiritual.

Kecerdasan spiritual disebut pula kecerdasan eksistensial adalah kemampuan untuk mengajukan pertanyaan-pertanyaan fundamental tentang eksistensi (keberadaan) atau pertanyaan tentang kerumitan suatu eksistensi (Wilson dalam Yaumi, 2013). Gardner (1999: 60) mengusulkan definisi kecerdasan spiritual sebagai kecerdasan eksistensial yang mampu menempatkan diri dalam hubungannya dengan suatu kosmos yang tak terbatas dan sangat kecil serta kapasitas untuk menempatkan diri dalam hubungannya dengan fitur-fitur eksistensial dari suatu kondisi manusia seperti makna kehidupan, arti kematian, perjalanan akhir dari dunia fisik dan psikologis, dan pengalaman mendalam tentang cinta kepada orang lain atau perendaman diri secara total dalam suatu karya seni. Secara khusus, Gardner tidak mengusulkan bahwa terdapat kecerdasan spiritual, religius, atau moral berdasarkan kebenaran dari suatu keyakinan individu, golongan, kelompok, atau institusi tertentu.

Meskipun demikian, kecerdasan spiritual belum sesuai dengan kriteria yang dikembangkan oleh Gardner sehingga kecerdasan ini dipandang belum sepenuhnya memenuhi syarat untuk masuk ke dalam teori kecerdasan jamak. Namun, terdapat alasan yang menjamin kecerdasan ini dimasukkan sebagai kecerdasan yang kesembilan dalam studi kecerdasan jamak. Amstrong (2009: 184185) memberikan petunjuk awal jika kecerdasan spitritual diterapkan dalam pembelajaran. Pertama, perlu ditekankan bahwa kecerdasan spiritual bukanlah untuk mempromosikan persoalan agama, spiritualitas, atau sistem kepercayaan tertentu, tetapi didedikasikan untuk mengkaji berbagai cara bagaimana manusia menjawab kekhawatiran eksistensial (baik menyangkut persoalan agama maupun yang bukan agama) termasuk keragaman cara yang dilakukan oleh berbagai pihak. Ada perlindungan konstitusional yang jelas untuk mengajar agama pada sekolah-sekolah umum secara objektif dan netral dan alasan pedagogis untuk menerapkan hal ini secara teratur melalui kurikulum.

Kedua, penerapan kecerdasan eksistensial masih memerlukan pertimbangan mendalam dan 
hati-hati dibandingkan delapan jenis kecerdasan lainnya. Menurut Amstrong hampir tidak terlihat keuntungan khusus dalam menerapkan kecerdasan eksistensial untuk setiap tujuan pendidikan walaupun kecerdasan ini sepenuhnya didukung oleh Howard Gardner sebagai kecerdasan resmi pada suatu hari nanti, tetap menjadi bagian yang berbeda dengan jenis kecerdasan lain. Ketiga, untuk menilai kecerdasan eksistensial pada peserta didik, atau untuk mengembangkan metode eksistensial dalam menilai topik-topik tertentu yang dikaji, sama sekali tidak produktif atau berguna dalam konteks pendidikan karena mereka cenderung untuk memaksa pendidik menciptakan kriteria yang terlalu membatasi nilai pedagogis sehingga mungkin hanya untuk mendorong munculnya kontroversi dan kebingungan baru.

Kekhawatiran Amstrong tersebut sebenarnya wajar-wajar saja dalam suatu masyarakat yang memisahkan agama dengan Negara bahkan dalam konteks kehidupan sehari-hari. Dalam suatu falsafah Negara Pancasila seperti halnya Indonesia, di mana sila pertamanya menyangkut "Ketuhanan Yang Maha Esa" penerapan kecerdasan eksistensial atau spiritual menjadi sangat penting artinya. Selain itu, paham kesatuan dalam keberagaman (unity in diversity) yang dianut bangsa Indonesia, menjadi petunjuk yang kuat untuk mengalamatkan kecerdasan eksistensial dalam pembelajaran. Oleh karena itu, penulis bisa memahami kehati-hatian Gardner dan Amstrong dalam memasukkan kecerdasan eksistensial sebagai kecerdasan yang kesembilan. Namun, tidak sedikit juga para pendidik telah menggolongkan kecerdasan ini ke dalam bahagian yang tak terpisahkan dengan kecerdasan jamak.

Connell (2005: 60) berbicara tentang kecerdasan spiritual dan mengatakan "Existential intelligence is the intelligence that Gardner refers to as half intelligence because he could not find a physiological location for it in the brain. I also call this a spiritual intelligence, as those who score high in this intelligence are concerned with life's big questions." Pernyataan ini paling tidak memberi isyarat yang jelas pada dua hal utama. Pertama, bahwa Howard Gardner sendiri masih mendudukkan kecerdasan spiritual sebagai kecerdasan setengah atau belum sempurna menjadi suatu kecerdasan hanya dengan alasan karena belum ditemukan lokasi fisiologisnya dalam otak manusia. Jika pernyataan ini benar, berarti kalau ditemukan tempatnya yang jelas dalam bagian otak manusia, maka Gardner dapat menerimanya sebagai kecerdasan yang sempurna. Kedua, kecerdasan eksistensial disebut juga kecerdasan spiritual karena fokus kajiannya menyangkut pertanyaan-pertanyaan besar dalam kehidupan manusia.

Gardner (1999: 54-60) ketika menjelaskan tentang kemungkinan adanya kecerdasan spiritual, dia membaginya dalam tiga komponen, yaitu (1) spiritual as concern with cosmic or existential issues; (2) spiritual as achievement of a state of being; dan (3) spiritual as effect on others. Maksudnya spiritual dalam hubungannya dengan kosmik atau isu-isu eksistensial, spiritual sebagai pencapaian keberadaan manusia, dan spiritual yang menimbulkan pengaruh bagi orang lain. Dengan demikian, sebenarnya Gardner sendiri telah memberi isyarat bahwa antara kecerdasan spiritual dan eksistensial memiliki bidang kajian yang sama untuk dilihat dan dikaji lebih dalam guna mengungkap bukti-bukti autentik yang dapat mengantarkan kepada kesimpulan untuk memasukkan secara resmi kecerdasan spiritual atau eksistensial ke dalam kajian kecerdasan jamak.

Kata spiritual memiliki akar kata spirit yang berarti roh. Kata ini berasal dari bahasa Latin, spiritus, yang berarti napas (Mitrafam, 2011). Roh bisa diartikan sebagai tenaga yang menjadi energi kehidupan, yang membuat manusia dapat hidup, bernapas dan bergerak. Dalam ajaran agama Kristen dijelaskan bahwa Roh Kudus adalah Allah, Roh Kudus adalah sebuah Pribadi yang memiliki akal budi, perasaan dan kehendak (Kisah Rasul 5:34 dan Yohanes 14:16, 26; 15:26). Begitu pula dalam Alquran dijelaskan bahwa:

\footnotetext{
"Katakanlah: Roh Kudus (Jibril) menurunkan Alquran itu dari Tuhanmu dengan benar, untuk meneguhkan (hati) orang-orang yang telah beriman, dan menjadi petunjuk serta kabar gembira bagi orang-orang yang berserah diri (kepada Allah)". (QS. 16:102).
}

Frase ruhu-alkudus, dalam ayat tersebut merujuk pada Malaikat Jibril yang diberi tugas mulia oleh Allah untuk membawa Alquran sebagai pedoman hidup manusia. Sedangkan, dalam kedua ayat berikut ini, ruh berdiri sendiri, tetapi didahului oleh haruf min yang diartikan roh ciptaanNya.

"Kemudian Dia menyempurnakan dan meniupkan ke dalam (tubuh)nya roh (ciptaan) Nya dan Dia menjadikan bagi kamu pendengaran, penglihatan dan hati; (tetapi) kamu sedikit sekali bersyukur (QS. 32:09)."

"Maka apabila Aku telah menyempurnakan kejadiannya dan - telah meniupkan ke dalamnya roh (ciptaan)-Ku, maka tunduklah kamu kepadanya dengan bersujud (QS, 15: 29)."

Menurut Nasri (2011) terdapat poin penting 
yang ada dalam dua ayat di atas bahwa jelas Allah bukan ruh sehingga harus memasukkan sebagian ruh-Nya ke dalam tubuh manusia, akan tetapi yang dimaksud oleh Alquran dengan penjelasan ini adalah kemuliaan dan ketinggian ruh itu sendiri, yakni ruh begitu bernilai sehingga Allah menghubungkannya dengan diri-Nya dan mengatakan "Aku meniupkan kepadanya ruh-Ku". Penjelasan dalam Kitab Injil dan Alquran seperti yang dipaparkan di atas menunjukkan bahwa nampaknya sulit kiranya istilah eksistensial, spiritual atau pekerti, tenaga, energi, dan roh dipisahkan dari ajar an agama seperti pandangan Gardner, Amstrong, McKenzie, dan Griffiths. Kecerdasan spiritual-eksistensial mendorong orang untuk memahami prosesproses dalam konteks yang besar, luas, dalam yang mencakup aspek-aspek estetika, filosofi, dan agama yang menekankan pada nilai-nilai keindahan klasik, kebenaran, dan kebaikan.

Berangkat dari kondisi objektif tersebut, maka tulisan ini diarahkan langsung pada rekonstruksi model pembelajaran berbasis kecerdasan spiritual untuk memperbaiki karakter peserta didik. Kebaikan karakter terbukti mampu dikonstruksi dari kecerdasan spiritual yang membangun kepribadian yang luhur baik dalam menjalankan syariat agama, membangun kesadaran yang tinggi, memiliki motivasi dan kepuasan kerja, serta menciptakaan kondisi belajar yang menyenangkan. Kajian ini bertujuan untuk menganalisis kondisi objektif pelaksanaan pembelajaran yang mengintegrasikan nilai-nilai karakter, mengonstruksi model pembelajaran berbasis kecerdasan spiritual untuk perbaikan karakter, dan kecenderungan perbaikan karakter yang terjadi dalam interaksi.

\section{Metode Penelitian}

Penelitian ini menggunakan metode penelitian kualitatif yang berhubungan dengan kajian terhadap fenomena sosial yang berusaha mencari jawaban tentang mengapa orang berprilaku seperti yang ditunjukkan, bagaimana sikap dan pandangan yang dibentuk, bagaimana orang dipengaruhi oleh suatu kejadian yang terjadi di sekitar mereka, bagaimana dan mengapa suatu budaya dapat berkembang, dan perbedaan-perbedaan dalam suatu kelompok sosial (Hancock, 2002). Penelitian ini dilakukan di SDN Centre Mangalli pada bulan Februari 2014-Agustus 2014 dengan melakukan observasi partisipan dalam bentuk partisipasi moderat terhadap pelaksanaan pembelajaran dari 26 informan (guru negeri dan honor), wawancara kelompok fokus (focus group interview) terhadap 26 informan ditambah dengan 1 informan (kepala sekolah, 1 komite, dan 1 orang pengawas sekolah tentang pembelajaran berbasis kecerdasan spiritual dan pelaksanaannya dalam ruang kelas, dan analisis dokumen tentang rencana pelaksanaan pembelajaran, instrumen penilaian kepengawasan, dan model perbaikan karakter peserta didik melalui program yang dikembangkan di sekolah. Analisis data dalam penelitian ini menggunakan analisis data kualitatif dengan merujuk pada tiga tahap analisis, seperti (1) reduksi data, (2) sajian data, dan (3) penarikan kesimpulan/ verifikasi (Miles dan Huberman, 1994).

\section{PEMBAHASAN}

Pembahasan diarahkan pada tiga komponen utama mencakup model integrasi nilai-nilai karakter dalam pembelajaran, model pembelajaran berbasis kecerdasan spiritual, model perbaikan karakter yang telah dilakukan dalam lingkungan sekolah SDN Centre Mangalli.

\section{Model Integrasi Nilai-nilai Karakter dalam Pembelajaran}

Hasil analisis terhadap 26 dokumen RPP yang digunakan oleh informan dan observasi partisipasi moderat terhadap pelaksanaan pembelajaran menunjukkan bahwa nilai-nilai karakter diintegrasikan melalui pengetahuan konten (content knowledge), proses pembelajaran, lingkungan belajar, kegiatan ekstrakurikuler, dan pemberdayaan budaya dan stuktur sosial dalam lingkungan sekolah, seperti dilustrasikan dalam gambar 1 .

\section{Gambar 1. Integrasi Nilai-nilai karakter}

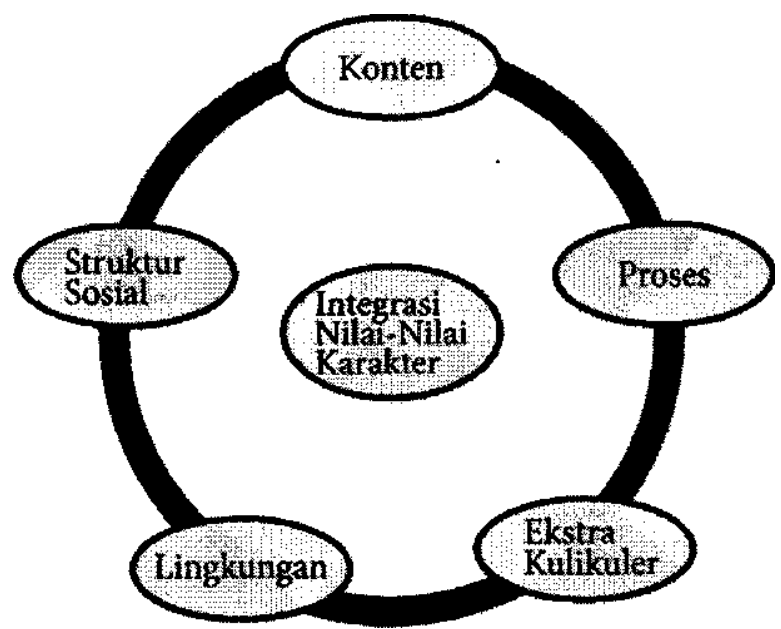

Pertama, integrasi konten adalah pemilihan isi pembelajaran yang berkaitan langsung dengan nilai-nilai karakter. Integrasi konten terdapat pada mata pelajaran Pendidikan Agama Islam dan PPKN khususnya pada pokok bahasan dan sub pokok bahasan tertentu bagi kelas VI, V, dan VI dan integrasi tema dan sub tema untuk kelas I, II, dan III. Dalam integrasi konten, peserta didik bukan 
hanya membaca dan menghafal tentang konsepkonsep yang berkenaan dengan nilai-nilai karakter melainkan juga mempraktikkanya. Adapun konten yang diintegrasikan dalam mata pelajaran pendidikan kewarganegaraan adalah mengetahui pertanggungjawaban kepala desa tanggung jawab), mengetahui partner kerjasama camat, Danramil dan Kapolsek (kerjasama), menyebutkan kewajiban daerah dalam penyelenggaraan otonomi daerah (kejujuran), menyimak pemahaman tentang kewenangan daerah provinsi (adil dan bijaksana), memahami manusia sebagai makhluk sosial (toleransi), menyebutkan contoh-contoh kebudayaan Indonesia (tarian tradisional) dan asing (cinta tanah air), mampu menjelaskan makna kesatuan wilayah Indonesia dari keempat segi kehidupan bernegara termasuk politik, sosial budaya, ekonomi, pertahanan-keamanan (toleransi, saling menghormati, respek), menunjukkan contohcontoh perilaku dalam menjaga keutuhan Negara Kesatuan Republik Indonesia (tanggung jawab dan kerjakeras).

Integrasi konten juga dapat dianalisis melalui tema-tema atau pokok bahasan dalam mata pelajaran pendidikan Agama Islam, seperti menyimak kisah keteladanan nabi dan rasul dalam Islam (religious), menyimak arti Asmaul Husna: ar-Rahman, ar-Rahim dan al-Malik (kasih sayang, adil), menyimak tatacara bersuci (mandi dan istinja) (suci, kerja keras), menunjukkan contoh perilaku bersih, sehat dan peduli lingkungan (bersih, sehat, peduli lingkungan), berdoa sebelum dan sesudah makan (religious), memiliki perilaku kerjasama dan tolong menolong secara (kerjasama, penolong), menyimak kisah keteladanan nabi Muhammad saw secara klasikal maupun individual seperti jujur, amanah, tablik, fathanah (jujur, amanah, ingin tahu, dan cerdas), memahami hadits yang terkait dengan perilaku mandiri, percaya diri, dan tanggung jawab (mandiri dan tanggung jawab), memahami makna sifat Allah qiyamuhu binafsihi, wahdaniyat, qudrah, dan iradah (mandiri, religius, ingin tahu, dan kerja keras), menjelaskan makna sikap santun dan menghargai teman (santun dan respek), menunjukkan perilaku saling mengingatkan (murah hati), menunjukkan sikap menghargai pendapat (respek), menyimak penjelasan tentang sikap sederhana (sederhana), menyimak penjelasan tentang sikap ikhlas (ikhlas), menunjukkan perilaku toleran dan simpati (toleransi dan simpati), dan menjelaskan contoh sikap berbaik sangka kepada sesama (prasangka baik). Jadi, nilai-nilai karakter yang diintegrasikan ke dalam konten pembelajaran adalah tanggung jawab, jujur, kerjasama, adil, bijaksana, toleran, cinta tanah air, saling menghormati, kerja keras, religius, kasih sayang, jujur, amanah, cerdas, peduli lingkungan, peduli sosial, mandiri, ingin tahu, santun, penolong, ikhlas, murah hati, dan sederhana.

Kedua, nilai-nilai karakter juga dapat ditelaah melalui proses pembelajaran yang diwujudkan dalam berbagai aktivitas pembelajaran. Secara sederhana aktivitas pembelajaran dapat dibagi ke dalam tiga komponen, yakni kegiatan pendahuluan, kegiatan inti, dan kegiatan penutup dan setiap kegiatan diintegrasikan nilai-nilai karakter yang dapat dijabarkan melalui tabel 1 berikut ini.

Tabel 1 Nilai-nilai Karakter dalam Proses Pembelajaran

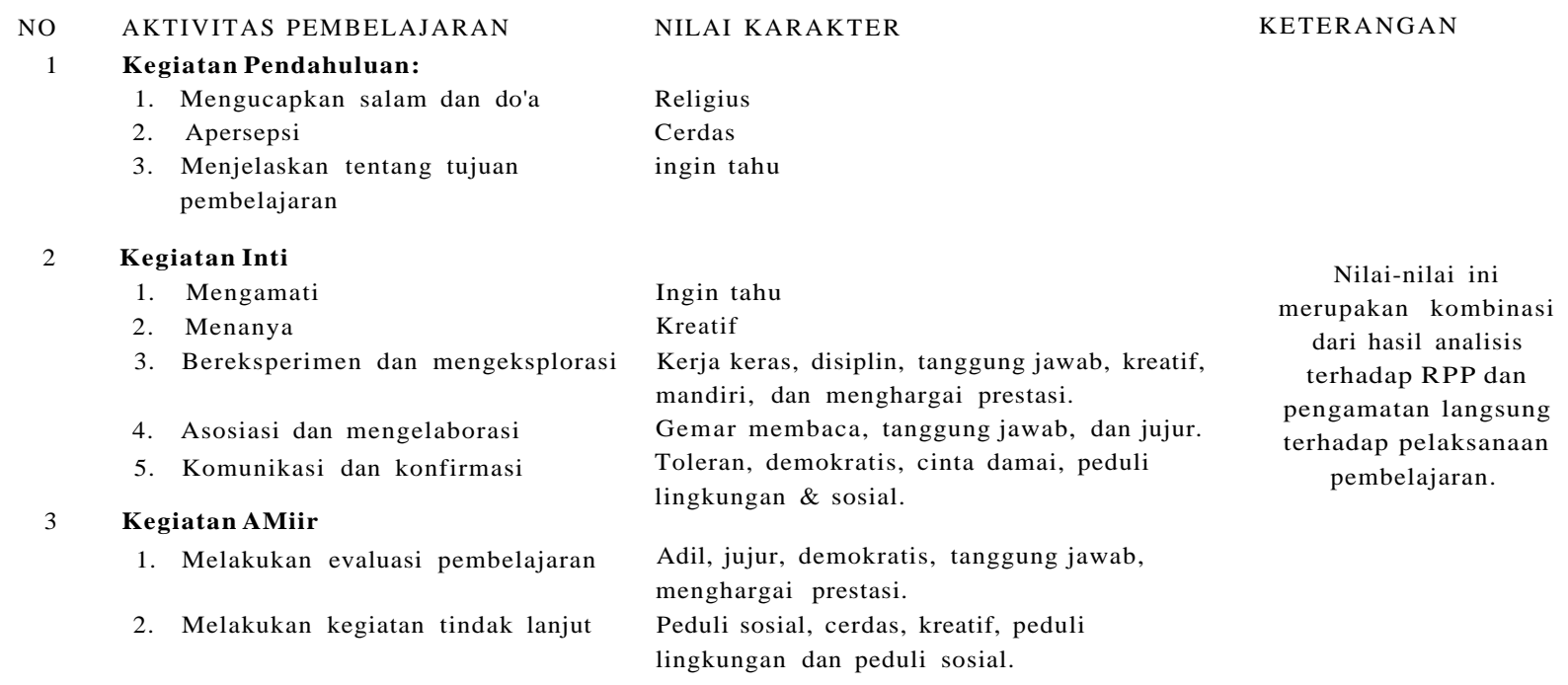


Ketiga, integrasi nilai-nilai karakter dalam kegiatan ekstrakurikuler mencakup, kegiatan kepramukaan, kegiatan olah raga (sepak bola, badminton, dan karate), kegiatan seni (musik, tari, dan media), dan kegiatan pengabdian (amal bakti sosial dan keterlibatan dalam menegakkan aturan). Hasil wawancara kelompok fokus menunjukkan bahwa nilai-nilai karakter yang diintegrasikan bertujuan untuk (1) melatih kemandirian, keberanian, ketangkasan melalui kegiatan kepramukaan; (2) melalih keuletan, daya juang, kerja keras, dan sportivitas melalui kegiatan olahraga; (3) mengembangkan sikap kemandirian, cinta damai, kreatif melalui seni musik, tari, dan media; dan (4) menumbuhkan sikap semangat kebangsaan, cinta tanah air, peduli sosial, dan peduli lingkungan melalui kegiatan pengabdian.

Keempat, integrasi nilai karakter melalui penciptaan lingkungan sekolah yang kondusif. Terdapat tiga jenis kegiatan yang berkenaan dengan pemeliharaan lingkungan sekolah, yakni melalui kegiatan kebersihan halaman sekolah dan ruang kelas, pemeliharaan tanaman dan tumbuh-tumbuhan, dan pembentukan kantin kejujuran di sekolah. Ketiga bentuk kegiatan ini melibatkan peserta didik sepenuhnya termasuk untuk menentukan berbagai kegiatan yang dilakukan untuk menunjang terciptanya suasana sekolah yang kondusif. Melalui kegiatan kebersihan peserta didik dilatih untuk mengembangkan sikap cinta lingkungan, budaya bersih, dan kerja keras. Melalui kegiatan pemeliharaan tanaman dan tumbuh-tumbuhan juga dapat peserta didik dapat bersikap peduli terhadap lingkungan. Begitupula melalui pembentukan kantin kejujuran dapat mengembangkan sikap jujur, kreatif, dan terbangun karakter tanggung jawab.

Kelima, integrasi nilai-nilai karakter melalui jalur struktur organisasi sekolah termasuk pembentukan struktur organisasi kepanitiaan harihari besar agama Islam, pembagian tugas kebersihan, personalia kepengurusan kepramukaan, dan tugas upacara yang diberikan secara bergilir terutama bagi kelas-kelas tinggi mulai dari kelas IV sampai dengan kelas VI. Karakter yang terbentuk dari kegiatan seperti ini adalah kemandirian, kreativitas, kejujuran, menghargai prestasi, kerja keras, dan kedisiplinan.

\section{Model Pembelajaran Berbasis Kecerdasan Spiritual}

Pelaksanaan pembelajaran yang dilaksanakan di SDN Centre Mangalli terutama kelas-kelas rendah masih dominan menerapkan metode

langsung (direct methods) seperti halnya ceramah. Namun seiring dengan perubahan kurikulum dan intensitas pelatihan dan pembinaan, perubahan dalam menggunakan pendekatan dan strategi pun terjadi. Pengamatan dilakukan secara terusmenerus yang berlangsung selama enam bulan untuk merumuskan langkah-langkah dan pola yang terjadi dalam melaksanakan pembelajaran. Pola pembelajaran tersebut, kemudian dikonstruksi dengan fokus pada implementasi pembelajaran yang mencakup menentukan strategi implementasi, mengikuti prosedur penerapan, memberikan tugas, mengawasi pelaksanaan, dan melakukan evaluasi, seperti pada gambar 2 .

Gambar 2 Model Pelaksanaan Pembelajaran

\section{Menentukan Strategi}

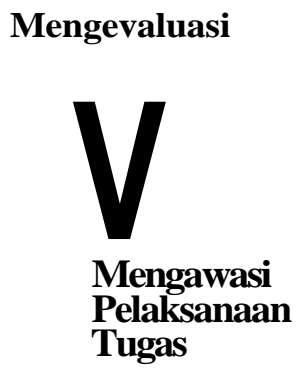

Hasil wawancara kelompok fokus menunjukkan bahwa strategi pembelajaran yang dapat mengembangkan kecerdasan spiritual mencakup respons kejadian, panggung beramal, puisi romantik, esai kritis, berdiskusi, menulis kreatif, interviu pemimpin, refleksi, simulasi, dan pertanyaan Sokrates. Respon kejadian adalah suatu strategi yang mengaitkan langsung tentang kejadian yang sangat menggembirakan dengan konten bahan pembelajaran yang sedang dipelajari. Kejadian yang tersebut dirumuskan kemudian diakhiri dengan pertanyaan-pertanyaan yang mengandung nilai nilai karakter. Panggung beramal adalah salah satu bentuk kegiatan ekstrakurikuler yang biasa dilakukan peserta didik di luar jam pelajaran. Kegiatan ini dilakukan untuk membantu individu, golongan, atau kelompok sosial masyarakat tertentu yang sedang ditimpa musibah atau sedang membutuhkan bantuan. Dengan ikhlas beramal itu diharapkan dapat mengatasi segala masalah yang dihadapi oleh orang tersebut. Puisi romantik 
adalah salah satu strategi yang diintegrasikan dalam pembelajaran bahasa di mana peserta didik diarahkan untuk mengonstruksi untaian kalimat dengan pilihan diksi dan kosa kata yang mengambarkan makna yang paling dalam di balik dari suatu peristiwa, atau benda.

Esai kritis merujuk pada hasil pemikiran secara tertulis tentang berbagai persoalan yang dihadapi dunia, negara, provinsi, kabupaten, atau persoalan internal suatu satuan pendidikan. Halhal yang dituangkan adalah pandangan kritis terhadap suatu peristiwa yang yang terjadi ditinjau dari eksistensinya. Selain itu, strategi pembelajaran berbasis kecerdasan spiritual adalah diskusi tentang persoalan-persoalan esensial dari suatu hal atau perkara yang mengungkap secara keseluruhan dengan pendekatan filosofis dan empiris. Menulis kreatif adalah menulis berbagai persoalan sederhana dan biasa dengan menggunakan tinjauan konseptual dan pragmatis untuk mengkaji kandungan makna dari suatu peristiwa. Interviu pemimpin adalah suatu metode pembelajaran yang mengungkap pandangan dari politisi, birokrasi, akademisi, agamawan, atau pemimpin lainnya yang bertujuan untuk mendapatkan jawaban dari beragam informasi yang berbeda-beda.

Strategi pembelajaran refleksi adalah mengkaji, menganalisis, dan mengevaluasi kembali segala sesuatu yang sudah dipahami secara benar atau yang belum diketahui secara komprehensif. Simulasi adalah mengongkritisasi hal-hal yang abstrak dengan menggunakan barang-barang tiruan sebagai representasi benda asli yang sedang dibahas. Simulasi dapat dilakukan dengan berbagai bentuk seperti game, penayangan gambar, atau dengan cara bermain peran. Strategi terakhir adalah pertanyaan Socrates menekankan pada pengajuan sejumlah pertanyaan yang diberikan pendidik kepada peserta didik, atau dari peserta didik yang satu kepada peserta didik yang lain dengan fokus pertanyaan secara berulang dan dikonstruksi dari jawaban peserta didik. Pertanyaan Socrates melibatkan penanya dengan penjawab secara aktif sehingga pertanyaan tidak pernah berakhir karena dikonstruksi dari jawaban yang diberikan. Tujuannya adalah untuk menciptakan kreativitas berpikir secara orisinal, mendalam, dan mengagungkan. Pendidik mengetahui konstruksi berpikir, organisasi ide, dan rumusan jawaban yang diberikan oleh peserta didik.

Setelah menentukan strategi yang sesuai dengan tujuan dan bahan ajar, tahapan selanjutnya adalah mengikuti prosedur dalam menerapkan pembelajaran. Prosedur adalah langkah sistematis untuk melaksanakan kegiatan atau tindakan yang ditentukan awal dan akhirnya yang harus diikuti menurut urutan yang sama untuk melakukan suatu tugas dengan benar. Contoh; St Mufida, Guru Kelas VI C, SDN Centre Manggalli memilih strategi respons kejadian dalam mengembangkan karakter jujur, respek, santun, dan berani. Prosedur pelaksanaan strategi respon kejadian sebagai berikut:

1. Guru menentukan isu-isu tertentu yang sesuai dengan perkembangan peserta didik dan mengulasnya dalam bahasa yang dapat dipahami peserta didik.

2. Guru mempresentasikan atau memberikan isu tersebut dalam bentuk tertulis berupa lembaranlembaran yang harus dibaca (tugas tersebut dapat dilakukan secara berkelompok atau mandiri).

3. Peserta didik memerhatikan presentasi guru atau membaca sajian informasi atau studi kasus yang telah diberikan guru.

4. Peserta didik menyimak, merefleksi, dan melakukan sintesis terhadap sajian informasi yang diberikan.

5. Hasil refleksi dan sintesis, diringkas atau diformulasikan, kemudian dikaji kembali agar dapat diungkap kandungan makna di balik peristiwa tersebut.

6. Peserta didik mengungkap kandungan nilai atau moral yang dapat dirumuskan dari peristiwa yang telah dikaji kemudian memberikan respons baik secara lisan diberikan di dalam ruang kelas maupun secara tertulis untuk dijadikan penilaian bagi guru.

Mengintegrasikan tugas adalah langkah ketiga setelah menentukan strategi dan mengikuti prosedur. Tugas yang diintegrasikan harus sesuai dengan persoalan aktual yang dapat dihubungkan secara langsung dengan materi pembelajaran. Adapun bentuk tugas yang diintegrasikan adalah berjudul 'Contekan Massal' dengan maksud mengaitkan peristiwa yang terjadi sebelumnya dengan mkemungkinan yang terjadi selama pelaksanaan ujian akhir tingkat SD yang berlangsung tanggal 19 Mei 2014. Wacana yang berjudul 'Contekan Massal' tersebut dirumuskan secara singkat yang terdiri atas lima paragraph. Pada akhir wacana tersebut diberikan pertanyaan yang mengandung nilainilai spiritual seperti "Bagaimana pandangan Anda tentang beberapa pernyataan di bawah ini?"

1. Kejujuran harus menjadi bagian dari kehidupan di mana, kapan, dan dalam kondisi apapun.

2. Penghargaan kepada orang lain harus
dikedepankan dalam menjaga kedamaian bersama. 
3. Pendidik hendaknya mengajarkan hal-hal yang baik dan benar kepada muridnya

4. Kesantunan dan penguasaan diri hendaknya dijunjung tinggi sehingga tidak melakukan tindakan brutal sebelum melihat hakikat masalahnya.

5. Kejujuran dan keberanian karena benar hendaknya menjadi pegangan hidup dalam menangani berbagai persoalan.

Tugas tersebut, kemudian dilakukan pengawasan mulai dari kegiatan membaca cepat tentang isi wacana tentang "Contekan Massai", kegiatan diskusi, pengambilan kesimpulan sampai pada pemaparan pandangan peserta didik tentang lima pernyataan di atas. Setelah itu dilakukan evaluasi baik yang terkait dengan pandangan peserta didik, maupun yang berhubungan dengan pelaksanaan strategi respon terhadap peristiwa termasuk tujuan, strategi, prosedur, tugas dan model pengawasan yang diberikan.

\section{Model Perbaikan Karakter}

Hasil pengamatan dan interviu terhadap 26 informan ditambah dengan kepala sekolah, komite, dan pengawas sekolah menunjukkan bahwa, SDN Centre Mangalli telah menerapkan pembelajaran berbasis kecerdasan spiritual dengan maksud untuk memperbaiki karakter peserta didik melalui tiga program pembelajaran berbasis spiritual yang disebut dengan 3 Pilar Spiritual, yakni Baca Tulis Alquran (BTQ), Taman Baca Sekolah (TBS), dan Kantin Kejujuran pada gambar 3.

Gambar 3. Tiga Pilar Kecerdasan Spiritual

\section{Baca Tulis Alquran-Qur'an}

\section{Kantin Kejujuran}

Kegiatan baca tulis Alquran dilakukan di luar jam pelajaran dengan pola pendidikan kolaboratif antara guru-guru agama bekerjasama dengan guru mengaji yang terdapat di beberapa Masjid sekitar sekolah. Peserta didik yang masuk sekolah pada pagi hari akan dibina pada sore hari selama 2 jam untuk setiap peserta didik dan dilakukan sebanyak tiga kali seminggu. Karakter yang dapat dikembangkan atau diperbaiki melalui program ini adalah religious, cerdas, ingin tahu, toleran, disiplin, dan demokratis.

Taman baca sekolah dibangun pada tiga titik dengan memanfaatkan taman yang dinaungi beberapa pohon kemudian ditata untuk menjadi tempat baca bagi peserta didik. Buku-buku diperoleh dari kumpulan novel yang sesuai dengan bacaan anak-anak, buku pelajaran, majalah, dan kumpulan kliping yang dibuat oleh peserta didik sebelumnya. Untuk mengaktifkan taman baca ini, sekolah mengadakan perlombaan secara berkala dan melibatkan seluruh guru dan peserta didik dari semua tingkatan. Karakter yang dibangun dari kegiatan ini adalah karakter ingin tahu, tekun, cerdas, gemar membaca, peduli sosial, peduli lingkungan, mandiri dan kreatif.

Kantin kejujuran adalah usaha bersama yang dibangun dalam area yang menyediakan segala macam keperluan peserta didik. Kantin ini tidak dijaga dan pelayanannya langsung dilakukan oleh peserta didik. Walaupun demikian, seluruh kebutuhan disediakan dan dilakukan pengecekan terhadap kekurangan pasokan oleh petugas yang ditunjuk dan diangkat oleh sekolah. Karakter yang dibangun dari kantin ini adalah kejujuran (jujur), tanggung jawab, dan mandiri.

\section{PENUTUP}

Berdasarkan pembahasan di atas, konstruksi model pembelajaran berbasis kecerdasan spiritual untuk perbaikan karakter dapat disimpulkan bahwa model integrasi nilai-nilai karakter dalam pembelajaran dapat dilakukan melalui integrasi pengetahuan konten (content knowledge), proses pembelajaran, lingkungan belajar, kegiatan ekstrakurikuler, dan pemberdayaan budaya dan stuktur sosial dalam lingkungan sekolah. Nilai-nilai karakter yang diintegrasikan ke dalam konten adalah tanggung jawab, jujur, kerjasama, adil, bijaksana, toleran, cinta tanah air, saling menghormati, kerja keras, religius, kasih sayang, jujur, amanah, cerdas, peduli lingkungan, peduli sosial, mandiri, ingin tahu, santun, penolong, ikhlas, murah hati, dan sederhana.

Model pembelajaran berbasis kecerdasan spiritualmencakuppenentuanstrategiimplementasi, prosedur penerapan, integrasi tugas, pengawasan pelaksanaan, dan evaluasi proses dan hasil. strategi pembelajaran yang dapat mengembangkan kecerdasan spiritual mencakup respons kejadian, panggung beramal, puisi romantik, esai kritis, berdiskusi, menulis kreatif, interviu pemimpin, refleksi, simulasi, dan pertanyaan Sokrates. 
Perbaikan karakter dilakukan dengan program pembelajaran yang menerapkan pembelajaran berbasis kecerdasan spiritual yang disebut 3 Pilar Spiritual, yakni Baca Tulis Alquran (BTQ), Taman Baca Sekolah (TBS), dan Kantin Kejujuran. Tiga program ini dilakukan secara kolaboratif antara pelibatan langsung masyarakat sebagai bagian dari program dengan komponen sekolah SDN Centre Mangalli.

\section{Ucapan Terima Kasih}

Ucapan terima kasih ditujukan kepada Dinas Pendidikan dan Kebudayaan Kabupaten Gowa, Kepala Sekolah SDN Centre Mangalli, ketua komite sekolah, pengawas, guru-guru dan peserta didik telah membantu peneliti selama pelaksanaan penelitian. Ucapan terima kasih pula diberikan kepada Lembaga Penelitian dan Pengabdian pada Masyarakat UIN Alauddin Makassar yang telah menyediakan dana demi terlaksananya penelitian ini.

\section{DAFTAR PUSTAKA}

Armstrong, Thomas. 2009. Multiple Intelligences in the Classroom, $3^{\mathrm{rd}}$ Edition, USA: ASCD.

Azizi, Maral. 2013. The Relationship between Spiritual Intelligence and Vocabulary Learning Strategies in EFL Learners. Theory and Practice in Language Studies, Vol. 3, No. 5, pp. 852-858, May.

Baharuddin, Elmi dan Ismail, Zainab. 2013. Hubungan Kecerdasan Rohaniah Warga Tua dengan Amalan Agamadi Rumah Kebajikan. Islamiyyat 35(1): 19 - 28 .

Connell, J Diana. 2005. Brain Based Strategies to Reach Every Learner: Surveys, Questionnaires, and Checklists that Help You Identify Students' Strengths-Plus Engaging Brain- Based Lessons and Activities, USA: Scholastic Inc.,

Dewantara, Ki Hajar. 1977. Pendidikan, Cetakan Kedua. Yogyakarta: Majelis Luhur Persatuan Taman Siswa.

Gardner, Howard. 1999. Intelligence Reframed, New York: Basic Books.

Hancock, Beverley. 2002. An Introduction to Qualitative Research. Nottingham: University of Nottingham.

http://mitrafm.com/blog/2008/12/15/kecerdasan- spiritual-menentukan-jati-diri

(Diakses

Tanggal 21 November, 2014).

Isfahani, Ali Nasr dan Nobakht, Marzieh. 2013. Impact of Spiritual Intelligence on the Staff Happiness (Case Study: Golpayegan Petrochemical Company). International Journal of Academic Research in Business and Social Sciences, July, Vol. 3, No. 7.

Jeloudar, Soleiman Y., dan Goodarzi, Fatemeh L. 2012. What Is the Relationship between Spiritual Intelligence and Job Satisfaction among MA and BA Teachers? International Journal of Business and Social Science. Vol. 3 No. 8, Special Issue - April.

Maimun, Agus. 2008. Pembelajaran Nilai di Sekolah Dasar. Jurnal Teknologi Pendidikan. Vol. 10 No.1, April.

Miles, Matthew B. dan Huberman, A Michael. 1994. Qualitative Data Analysis, Second Edition. California: Sage Publication, Inc.

Mitrafam. 2014. Kecerdasan Spiritual Menentukan JatiDiri. Online:

Mosaybian, Nafiseh dan Araghizade, Asgar. 2014. Surveying the Effect of Spiritual Intelligence on Employee Empowerment. Arabian Journal of Business and Management. Review Vol. 3, No.6 (a); February.

Nasri, Abdullah. 2011. Manusia, Ruh dan Al-Quran. Online: $\quad$ http://www.al-shia.org/html/id/ quran/buku-dan/12.htm (Diakses Tanggal 21 November, 2014).

Prawiradilaga, Dewi, S. 2009. Prinsip Desain Pembelajaran.: Instructional Design Principles. Jakarta: Kencana Prenada Media Group.

Reigeluth, Charles M. dan Carr-Chellman, Alison A. 2009. Instructional-Design Theories and Models Volume III: Building a Common Knowledge Base. New York: Routledge.

Snelbecker, Glenn E. 1974. Learning Theory, Instructional Theory, and Psychoeducational Design. New York: McGraw-Hill Book Campany.

Yaumi, Muhammad. 2013. Pembelajaran Berbasis Kecerdasan Jamak (Multiple Intelligences: Mengidentifikasi dan Mengembangkan Multitalenta Anak. Jakarta: Kencana Prenada Media Group. 2014. Pendidikan Karakter: Landasan, Pilar, dan Implementasi. Jakarta: Kencana Prenadamedia Group. 